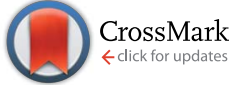

Cite this: RSC Adv., 2015, 5, 73726

Received 18th June 2015

Accepted 25th August 2015

DOI: $10.1039 / \mathrm{c} 5 \mathrm{ra11756a}$

www.rsc.org/advances

\title{
Photophysical and photochemical properties of a family of isoelectronic tris chelated ruthenium(II) aza-/azo-aromatic complexes
}

\begin{abstract}
Samir Das*a and Basudev Pradhan*b
We have investigated the electrochemical, spectroscopic and electroluminescent properties of a family of aza-aromatic complexes of ruthenium of type $\left[R u^{\prime \prime}(b p y / p h e n)_{2}(L)\right]^{2+}\left(4 d^{6}\right)$ with three isomeric $L$ ligands, where, bpy $=2,2^{\prime}$-bipyridine, phen $=1,10$-phenanthroline and the $\mathrm{L}$ ligands are 3 -(2-pyridyl) $[1,2,4]$ triazolo[1,5-a]pyridine $\left(L^{1}\right), 3$-(2-pyridyl[1,2,3])triazolo[1,5-a]pyridine $\left(L^{2}\right)$ and 2-(2-pyridyl) $[1,2,4]$ triazolo[1,5-a]pyridine $\left(L^{3}\right)$. The complexes display two bands in the visible region near $410-420$ and 440-450 nm. The complexes are diamagnetic and show well defined ${ }^{1} \mathrm{H}$ NMR lines. They are electroactive in acetonitrile solution and exhibit a well defined $\mathrm{Ru}$ "I/Ru $\mathrm{u}^{\mathrm{III}}$ couple near 1.20 to $1.30 \mathrm{~V}$ and -1.40 to $-1.50 \mathrm{~V}$ due to ligand reduction versus Saturated Calomel Electrode (SCE). The solutions are also luminescent, with peaks are near $600 \mathrm{~nm}$. All the complexes are electroluminescent in nature with peaks lying near $580 \mathrm{~nm} . \mathrm{L}^{1}$ and $\mathrm{L}^{3}$ ligated complexes with two bpy co-ligands show weak photoluminescence $(\mathrm{PL})$ but stronger electroluminescence $(\mathrm{EL})$ compared to corresponding $\mathrm{L}^{2}$ ligated analogues.
\end{abstract}

\section{Introduction}

The past few years have seen a rapid development in the chemistry, biochemistry and photophysics of aza-aromatic complexes of ruthenium. Aza-aromatic complexes of ruthenium are extensively used as photosensitizers, for production of $\mathrm{H}_{2}$ and $\mathrm{O}_{2}$ from $\mathrm{H}_{2} \mathrm{O},{ }^{1-5}$ and for biological sensing. ${ }^{6,7}$ Cyclic azaaromatic complexes of ruthenium are used as sensitizers in dyesensitized solar cells. ${ }^{\mathbf{8 - 1 4}}$ Aza-aromatic ruthenium(II) complexes are also promising candidates for incorporating into low voltage, single-layer, solid-state electroluminescent devices, such as light emitting diodes (LEDs), as they have high photoredox efficiencies. ${ }^{15-33}$

Electroluminescent devices using transition metal dyes typically use unsubstituted and peripheral hydrogen substituted polypyridyl complexes of ruthenium and other transition metal complexes. ${ }^{34}$ However, nitrogen rich heterocyclic ligands, complexing with platinum, iridium and other transition metals, have been extensively used to synthesize light-emitting self-assembled materials. ${ }^{35,36}$ In order to explore the activity of nitrogen rich heterocyclic ligands in electroluminescent devices, we developed three isomeric triazolopyridine ligands $\left(\mathrm{L}^{1}-\mathrm{L}^{3}\right)$ and their ionic ruthenium dye

${ }^{a}$ California Institute of Technology, Pasadena, California, USA. E-mail: samir@ caltech.edu

${ }^{b}$ Centre for Energy Engineering, Centre of Excellence (CoE) in Green and Efficient Energy Technology (GEET), Central University of Jharkhand, Ranchi, India. E-mail: basudev.pradhan@cuj.ac.in complexes with bipyridine or $o$-phenanthroline co-ligands. The complexes display two $\pi(\mathrm{Ru})-\pi^{*}(\mathrm{~L})$ metal to ligand charge transfer (MLCT) excitation bands of moderate intensity in the visible region, near $410-420$ and $440-450 \mathrm{~nm}$, in addition to the standard heterocyclic UV region band in acetonitrile. The solutions are also luminescent, with absorbance peaks near $600 \mathrm{~nm}$. Excitation spectral studies have demonstrated that the luminescence is associated with the above noted MLCT bands. The redox behavior in acetonitrile are characterized through a one-electron oxidation of the ruthenium center at $1.20-1.30 \mathrm{~V}$ and a one electron reduction of the ligand at $-1.40-1.50 \mathrm{~V}$ versus saturated calomel electrode (SCE).

\section{Experimental section}

\section{Materials}

$\left[\mathrm{Ru}(\mathrm{bpy})_{2} \mathrm{Cl}_{2}\right]$ and $\left[\mathrm{Ru}(\text { phen })_{2} \mathrm{Cl}_{2}\right]$ were prepared as reported earlier. ${ }^{37}$ For electrochemical work HPLC grade acetonitrile was used. All other chemicals and solvents were of reagent grade and were used as received.

\section{Physical measurements}

${ }^{1} \mathrm{H}$ and ${ }^{13} \mathrm{C}$ NMR spectra were recorded with a Bruker FT $300 \mathrm{MHz}$ spectrometer. Spin-spin structures are abbreviated as follows: s, singlet; d, doublet; t, triplet. Electrochemical measurements were performed under nitrogen atmosphere using a $\mathrm{CH}$ 620A electrochemical analyzer, with platinum 
working electrode. The supporting electrolyte was tetraethylammonium perchlorate (TEAP), and the potentials were referenced to the saturated calomel electrode (SCE) without junction correction. Microanalysis (C, H, N) was performed using a Perkin-Elmer 2400 series II analyzer. Mass spectra were measured with Q-TOF mass spectrometer (MeCN). UV-vis absorption spectra and florescence spectra of the ruthenium complexes in acetonitrile solution were recorded with a UV1601 PC spectrophotometer and Perkin-Elmer model LS 55 luminescence spectrometer respectively. The solutions used for emission and life time measurements were de-aerated by bubbling nitrogen gas for $30 \mathrm{~min}$. Florescence life times were determined from time-resolved intensity decay by the method of time-correlated single-photon counting using a picoseconds diode laser (IBH, UK, nanoled-07) as the light source. The decays were analyzed using IBH DAS-6 decay analysis software.

\section{Determination of quantum yield $(\Phi)$}

Quantum yields were determined by comparing with a $\left[\mathrm{Ru}(\mathrm{bpy})_{3}\right]^{2+}$ standard $\left(\Phi_{\mathrm{s}}=0.042\right)$ measured in aqueous solution. ${ }^{38}$ The relevant formula is given in the following equation:

$$
\Phi_{\mathrm{x}}=\left[\Phi_{\mathrm{s}}\left(A_{\mathrm{s}} \times I_{\mathrm{x}}\right) /\left(A_{\mathrm{x}} \times I_{\mathrm{s}}\right)\right]\left(\eta_{\mathrm{x}} / \eta_{\mathrm{s}}\right)^{2}
$$

here $\mathrm{x}$ and $\mathrm{s}$ subscripts refer to the experimental sample and standard respectively. $A$ is the absorbance (set near 0.1 in a $1 \mathrm{~cm}$ cell) at the peak (436 nm in the case of the standard), $I$ is the area under the emission spectrum and $\eta$ is the refractive index of the solvent used.

\section{Electroluminescence study}

Light emitting devices were fabricated on indium tin oxide (ITO) coated glass substrates, which were cleaned and processed following standard protocol. Ruthenium complexes were first dissolved in acetonitrile $\left(2 \mathrm{mg} \mathrm{ml}^{-1}\right)$ and were spin coated on the ITO-coated glass substrate at $2000 \mathrm{rpm}$ for $60 \mathrm{~s}$. The films were dried for $12 \mathrm{~h}$ at $110{ }^{\circ} \mathrm{C}$ under vacuum oven $\left(10^{-3}\right.$ Torr). The thicknesses of the films were around $75 \mathrm{~nm}$ (as measured by a Planar Products Limited SF101 surfometer). Aluminium (Al) was vacuum-evaporated on top of the annealed films from a tungsten filament basket at a pressure below $10^{-5}$ Torr. Active area of each of the devices was $6 \mathrm{~mm}^{2}$. The electrical characteristics of the devices were measured in a shielded vacuum chamber with a Yokogawa $7651 \mathrm{dc}$ source and a Keithley 486 picoammeter. The radiance of the devices were measured with a Keithley 617 electrometer, and a Si photodiode (Centronics Co. OSD100-5T). ITO was used as the anode for all electrical measurements. The electroluminescence spectra were measured with a Horiba Jobin Yvon (Fluromax-3) luminescence spectrometer. The instruments were controlled with a personal computer via a general-purpose interface bus (GPIB).

\section{Synthesis of ligands}

$\mathrm{L}^{1}$ and $\mathrm{L}^{2}$ ligands were prepared by literature methods while ligand $\mathrm{L}^{3}$ was prepared slightly modifying the literature method. ${ }^{38-41}$

\section{Synthesis of ligand $\left(\mathrm{L}^{3}\right)$}

2-Cyanopyridine ( $500.00 \mathrm{mg}, 4.76 \mathrm{mmol}$ ) was condensed with 2aminopyridine (452.00 $\mathrm{mg}, 4.76 \mathrm{mmol}$ ) to form $N$-(2-pyridyl)-2pyridinecarboamidine and then the product was added to a mixture of acetic acid and acetic anhydride $(1: 1)$ at $0{ }^{\circ} \mathrm{C}$. The solution was then brought to room temperature and stirred for $2 \mathrm{~h}$. The solution was then refluxed for $2 \mathrm{~h}$. The resulting compound was then treated with dil. $\mathrm{HCl}$ with aq. $\mathrm{NaOCl}$. Yield: $518.00 \mathrm{mg}(55 \%) .{ }^{1} \mathrm{H}$ NMR $\left(\mathrm{CDCl}_{3}\right), \delta 8.65$ (triazolofused-py-H6, $1 \mathrm{H}, \mathrm{d}, J=4.68 \mathrm{~Hz}$ ), 8.43 (triazolofused-py-H3, $1 \mathrm{H}, \mathrm{d}, J=8.37$ $\mathrm{Hz}$ ), 7.91 (triazolofused-py-H4, $1 \mathrm{H}, \mathrm{t}, \quad J=9.01 \mathrm{~Hz}$ ), 7.77 (triazolofused-py- $\mathrm{H} 5,{ }^{1} \mathrm{H}, \mathrm{t}, J=8.75 \mathrm{~Hz}$ ), py-protons: 8.37 (py-H6', 1H, d, $J=6.57 \mathrm{~Hz}$ ), 8.29 (py-H3', 1H, d, $J=7.56 \mathrm{~Hz}$ ), 7.50 (py-H4', 1H, t, $J=9.91 \mathrm{~Hz}$ ), $7.08\left(\mathrm{H}^{\prime}, 1 \mathrm{H}, \mathrm{t}, J=9.95 \mathrm{~Hz}\right.$ ).

\section{Synthesis of complexes}

Five complexes were synthesized by the same general procedures and the details are described for one complex.

$\left[\mathrm{Ru}(\mathrm{bpy})_{2}\left(\mathrm{~L}^{2}\right)\right]\left(\mathrm{PF}_{6}\right)_{2}$, II: $\mathrm{L}^{2}(40.58 \mathrm{mg}, 0.207 \mathrm{mmol})$ was added to a hot solution of $\left[\mathrm{Ru}(\mathrm{bpy})_{2} \mathrm{Cl}_{2}\right](100 \mathrm{mg}, 0.207 \mathrm{mmol})$ in ethanol. On subsequent heating under reflux for $1 \mathrm{~h}$, the solution color changed from reddish brown to orange. The volume of the solvent was reduced under reduced pressure, and ammonium hexafluorophosphate $\left(\mathrm{NH}_{4} \mathrm{PF}_{6}\right)$ was added to solution. The orange microcrystalline product was collected by filtration. The solid mass thus obtained was repeatedly washed with ethanol and ether. The solid was dissolved in minimum volume of acetonitrile and subjected to chromatography on a silica gel column $(10 \times 1 \mathrm{~cm}, 60-120 \mathrm{mesh})$ prepared in toluene. The complex was eluted with acetonitrile-toluene mixture $(1: 1)$. Yield $=134.07 \mathrm{mg}(72 \%) .{ }^{1} \mathrm{H}$ NMR $\left(\mathrm{CD}_{3} \mathrm{CN}\right) \delta 8.66$ (triazolofused-py-H6, 1H, d, $J=7.07 \mathrm{~Hz}$ ), 8.48 (triazolofused-py$\mathrm{H} 3,1 \mathrm{H}, \mathrm{d}, J=8.70 \mathrm{~Hz}$ ), 8.42 (triazolofused-py-H4, $1 \mathrm{H}, \mathrm{t}, J=7.92$ $\mathrm{Hz}$ ), 8.31 (triazolofused-py-H5, ${ }^{1} \mathrm{H}, \mathrm{t}, J=7.54 \mathrm{~Hz}$ ), py-protons: 8.44-7.31, ${ }^{13} \mathrm{C}$ NMR $\left(\mathrm{CD}_{3} \mathrm{CN}\right) \delta 157.56,157.51,157.31,152.56$, 152.46, 152.24, 152.22, 138.45, 138.29, 138.28, 138.16, 138.15, 138.08, 130.95, 129.90, 128.02, 127.96, 127.94, 127.88, 127.24, 127.02 , 125.41, 124.69, 124.56, 124.23, 123.93, 122.30, 122.12, 118.46, 117.75, 117.18. MS ( $m / z$, ESI), $755.08\left(: \mathrm{M}-\mathrm{PF}_{6}+\mathrm{H}^{+}\right)$, 304.91 (:M - 2PF $)$. Elemental analysis calculated for $\mathrm{C}_{31} \mathrm{H}_{24}$ $\mathrm{N}_{8} \mathrm{RuP}_{2} \mathrm{~F}_{12}$ : C, 41.39, H, 2.69, N, 12.46 found: C, 41.13, H, 2.57, $\mathrm{N}, 12.28$.

$\left[\mathrm{Ru}(\mathrm{bpy})_{2}\left(\mathrm{~L}^{1}\right)\right]\left(\mathrm{PF}_{6}\right)_{2}, \mathrm{I}: \mathrm{L}^{1}(40.58 \mathrm{mg}, 0.207 \mathrm{mmol})$ and $100 \mathrm{mg}$ $(0.207 \mathrm{mmol})\left[\mathrm{Ru}(\mathrm{bpy})_{2} \mathrm{Cl}_{2}\right]$ were employed. Yield $=147.10 \mathrm{mg}$ (79\%). ${ }^{1} \mathrm{H}$ NMR $\left(\mathrm{CD}_{3} \mathrm{CN}\right) \delta 8.86$ (triazolofused-py-H6, $1 \mathrm{H}, \mathrm{d}, J=$ $7.03 \mathrm{~Hz}$ ), 8.47 (triazolofused-py-H3, 1H, d, $J=8.07 \mathrm{~Hz}$ ), 8.44 (triazolofused-py-H4, 1H, t, $J=7.97 \mathrm{~Hz}$ ), 8.41 (triazolofused-py$\mathrm{H} 5,1 \mathrm{H}, \mathrm{t}, J=7.77 \mathrm{~Hz})$, py-protons: $8.39-7.29,{ }^{13} \mathrm{C} \mathrm{NMR}\left(\mathrm{CD}_{3} \mathrm{CN}\right)$ $\delta 153.32,152.83,152.79,152.30,152.21,138.38,138.26,138.11$, $138.05,137.89$, 131.10, 127.93, 127.86, 127.83, 127.22, 126.82, 
124.92, 124.67, 124.51, 124.04, 123.92, 122.77, 122.51, 122.35, 122.11, 122.01, 121.67, 118.28, 117.70, 117.33, 116.54. MS $(\mathrm{m} / \mathrm{z}$, ESI), $755.08\left(: \mathrm{M}-\mathrm{PF}_{6}+\mathrm{H}^{+}\right), 305.05\left(: \mathrm{M}-2 \mathrm{PF}_{6}\right)$. Elemental analysis calculated for $\mathrm{C}_{31} \mathrm{H}_{24} \mathrm{~N}_{8} \mathrm{RuP}_{2} \mathrm{~F}_{12}$ : C, 41.39, H, 2.69, N, 12.46 found: $\mathrm{C}, 41.10, \mathrm{H}, 2.47, \mathrm{~N}, 12.33$.

$\left[\mathrm{Ru}(\mathrm{bpy})_{2}\left(\mathrm{~L}^{3}\right)\right]\left(\mathrm{PF}_{6}\right)_{2}, \mathrm{III}: \mathrm{L}^{3}(40.58 \mathrm{mg}, 0.207 \mathrm{mmol})$ and 100 $\mathrm{mg}(0.207 \mathrm{mmol})\left[\mathrm{Ru}(\mathrm{bpy})_{2} \mathrm{Cl}_{2}\right]$ were employed. Yield $=139.65$ $\mathrm{mg}(75 \%) .{ }^{1} \mathrm{H}$ NMR $\left(\mathrm{CD}_{3} \mathrm{CN}\right) \delta 8.83$ (triazolofused-py-H6, $1 \mathrm{H}, \mathrm{d}, J$ $=7.00 \mathrm{~Hz}$ ), 8.44 (triazolofused-py-H3, $1 \mathrm{H}, \mathrm{d}, J=8.13 \mathrm{~Hz}$ ), 8.42 (triazolofused-py-H4, $1 \mathrm{H}, \mathrm{t}, J=7.92 \mathrm{~Hz}$ ), 8.40 (triazolofused-py$\left.\mathrm{H} 5,{ }^{1} \mathrm{H}, \mathrm{t}, J=7.65 \mathrm{~Hz}\right)$, py-protons: $8.40-7.28,{ }^{13} \mathrm{C} \mathrm{NMR}\left(\mathrm{CD}_{3} \mathrm{CN}\right)$ $\delta$ 154.33, 153.14, 152.57, 152.31, 152.12, 138.31, 138.26, 138.01, 138.00, 137.83, 131.00, 127.64, 127.57, 127.33, 127.02, 126.21, $125.92,124.45,124.33,124.09,123.81,122.77,122.49,122.41$, 122.09, 122.02, 121.63, 119.01, 117.90, 117.76, 116.92. MS $(\mathrm{m} / \mathrm{z}$, ESI), $755.07\left(: \mathrm{M}-\mathrm{PF}_{6}+\mathrm{H}^{+}\right), 305.06\left(: \mathrm{M}-2 \mathrm{PF}_{6}\right)$. Elemental analysis calculated for $\mathrm{C}_{31} \mathrm{H}_{24} \mathrm{~N}_{8} \mathrm{RuP}_{2} \mathrm{~F}_{12}$ : C, 41.39, $\mathrm{H}, 2.69, \mathrm{~N}$, 12.46 found: C, 41.11, H, 2.43, N, 12.23.

$\left[\mathrm{Ru}(\text { phen })_{2}\left(\mathrm{~L}^{1}\right)\right]\left(\mathrm{PF}_{6}\right)_{2}, \mathrm{IV}: \mathrm{L}^{1}(36.85 \mathrm{mg}, 0.188 \mathrm{mmol})$ and 100 $\mathrm{mg}(0.188 \mathrm{mmol})\left[\mathrm{Ru}(\mathrm{phen})_{2} \mathrm{Cl}_{2}\right]$ were employed. Yield $=121.14$ $\mathrm{mg}(68 \%) .{ }^{1} \mathrm{H}$ NMR $\left(\mathrm{CD}_{3} \mathrm{CN}\right) \delta 8.86$ (triazolofused-py-H6, $1 \mathrm{H}, \mathrm{d}, J$ $=7.01 \mathrm{~Hz}$ ), 8.52 (triazolofused-py-H3, 1H, d, $J=9.21 \mathrm{~Hz}$ ), 8.47 (triazolofused-py-H4, 1H, t, $J=8.55 \mathrm{~Hz}$ ), 8.43 (triazolofused-py$\mathrm{H} 5,{ }^{1} \mathrm{H}, \mathrm{t}, J=7.00 \mathrm{~Hz}$ ), py-protons and $\mathrm{CH}$ protons of phen: 8.42-7.10, ${ }^{13} \mathrm{C}$ NMR $\left(\mathrm{CD}_{3} \mathrm{CN}\right) \delta 157.55,157.47,157.31,157.09$, $153.33,152.85,152.80,152.59$, 152.31, 152.21, 147.7, 139.00, 138.39, 138.26, 138.11, 138.05, 131.11, 129.33, 128.22, 127.94, $127.88,127.85,127.23,126.84,124.94,124.69,124.52,124.04$, 123.92, 122.80, 118.74, 118.34, 117.74, 117.33, 116.13, 115.64. $(m / z$, ESI $), 803.28\left(: \mathrm{M}-\mathrm{PF}_{6}+\mathrm{H}^{+}\right), 329.14\left(: \mathrm{M}-2 \mathrm{PF}_{6}\right)$. Elemental analysis calculated for $\mathrm{C}_{35} \mathrm{H}_{24} \mathrm{~N}_{8} \mathrm{RuP}_{2} \mathrm{~F}_{12}$ : C, 44.36, H, 2.55, N, 11.82 found: $\mathrm{C}, 44.13, \mathrm{H}, 2.69, \mathrm{~N}, \mathbf{1 1 . 7 1}$.

$\left[\mathrm{Ru}(\text { phen })_{2}\left(\mathrm{~L}^{2}\right)\right]\left(\mathrm{PF}_{6}\right)_{2}, \mathrm{~V}: \mathrm{L}^{2}(36.85 \mathrm{mg}, 0.188 \mathrm{mmol})$ and 100 $\mathrm{mg}(0.188 \mathrm{mmol})\left[\mathrm{Ru}(\mathrm{phen})_{2} \mathrm{Cl}_{2}\right]$ were employed. Yield $=121.14$ $\mathrm{mg}(68 \%) .{ }^{1} \mathrm{H} \mathrm{NMR}\left(\mathrm{CD}_{3} \mathrm{CN}\right) \delta 8.78$ (triazolofused-py-H6, $1 \mathrm{H}, \mathrm{d}, J$ $=7.13 \mathrm{~Hz}$ ), 8.52 (triazolofused-py-H3, $1 \mathrm{H}, \mathrm{d}, J=8.00 \mathrm{~Hz}$ ), 8.38 (triazolofused-py-H4, $1 \mathrm{H}, \mathrm{t}, J=7.55 \mathrm{~Hz}$ ), 8.32 (triazolofused-py$\mathrm{H} 5,{ }^{1} \mathrm{H}, \mathrm{t}, J=7.57 \mathrm{~Hz}$ ), py-protons and $\mathrm{CH}$ protons of phen: 8.55-7.10, ${ }^{13} \mathrm{C}$ NMR $\left(\mathrm{CD}_{3} \mathrm{CN}\right) \delta 154.47,153.99,153.64,153.49$, $153.37,153.32,153.28,152.76,152.22$, 139.03, 138.41, 138.22, $137.80,137.26,137.20,137.01,130.87,129.42,129.33,128.65$, 128.60, 128.54, 128.44, 128.32, 128.22, 126.91, 126.45, 126.39, 126.32, 125.70, 125.21, 122.23, 118.37, 117.74 117.15. ( $\mathrm{m} / \mathrm{z}, \mathrm{ESI})$, 802.25 (:M - $\left.\mathrm{PF}_{6}\right), 328.76\left(: \mathrm{M}-2 \mathrm{PF}_{6}\right)$. Elemental analysis calculated for $\mathrm{C}_{35} \mathrm{H}_{24} \mathrm{~N}_{8} \mathrm{RuP}_{2} \mathrm{~F}_{12}: \mathrm{C}, 44.36, \mathrm{H}, 2.55, \mathrm{~N}, 11.82$ found: $\mathrm{C}, 44.10, \mathrm{H}, 2.67, \mathrm{~N}, 11.66$.

\section{Results and discussions}

\section{Synthesis}

Three isomeric ligands $\left(\mathrm{L}^{1}-\mathrm{L}^{3}\right)$ were synthesized, which, in addition to bpy and phen co-ligands, vary in position of nitrogen and fused pyridine ring. The heteroleptic $\mathrm{Ru}(\mathrm{II})\left(4 \mathrm{~d}^{6}\right)$ complexes I-V were synthesized by refluxing $\left[\mathrm{Ru}(\mathrm{bpy} / \mathrm{phen})_{2} \mathrm{Cl}_{2}\right]$ with $\mathrm{L}$ in boiling ethanol for an hour. The orange colored $\left.\left[\mathrm{Ru}(\mathrm{bpy} / \text { phen })_{2} \mathrm{~L}\right)\right]^{2+}$ were precipitated with an excess of $\mathrm{NH}_{4} \mathrm{PF}_{6}$ and purified by column chromatography on silica gel, using a mixture of acetonitrile and toluene.
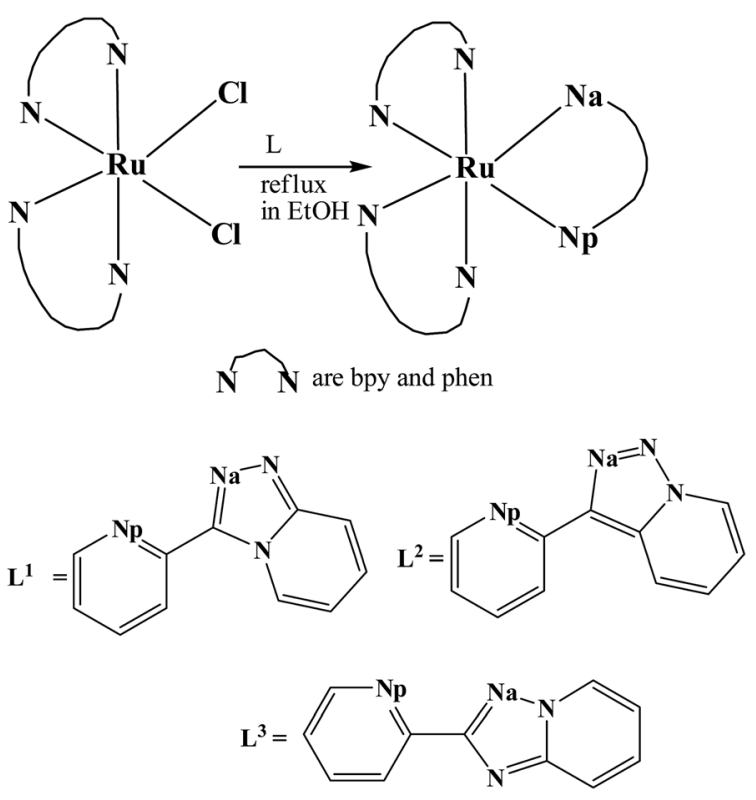

\section{Spectra and electrochemistry}

In addition to standard aza-aromatic signatures in the UV region, the complexes (in acetonitrile) display bands of moderate intensity in the visible region near 410-420 and 440$450 \mathrm{~nm}$ (Table 1), similar to standard Ru(bpy) ${ }_{3}$ complexes. ${ }^{28}$ The spectra of the complexes are displayed in Fig. 1. These bands have been assigned to $\mathrm{d}(\mathrm{Ru})-\pi^{*}(\mathrm{~L})$ MLCT transitions. The complexes display well-resolved ${ }^{1} \mathrm{H}$ and ${ }^{13} \mathrm{C}$ NMR in $\mathrm{CD}_{3} \mathrm{CN}$ solution. The ${ }^{1} \mathrm{H}$ NMR and ${ }^{13} \mathrm{C}$ NMR spectra of the complexes have peaks corresponding to the six-membered and fivemembered azo-aromatic protons and carbons, at 8.90 to 7.10 ppm and at 160 to 115 ppm respectively, as has been observed in literature. ${ }^{38,39,42-44}$ The NMR data are given in the experimental section.

The electrochemical behaviors of the complexes in acetonitrile were investigated. The results are listed in Table 2. The cyclic voltammograms of the complexes contain one electron oxidation wave and one electron reduction wave. The oxidation potentials for all complexes range from 1.20 to $1.30 \mathrm{~V}$ due to the $\mathrm{Ru}^{\mathrm{II}} / \mathrm{Ru}^{\mathrm{III}}$ couple, and the reduction potentials for all complexes range from -1.40 to $-1.45 \mathrm{~V}$, due to ligand reduction versus SCE (Table 2). The oxidation potentials of the complexes decrease in the order of coordinated ligands $\mathrm{L}^{2}>\mathrm{L}^{1} \approx \mathrm{L}^{3}$, due to the presence of three conjugative electron-withdrawing nitrogen atoms $(\mathrm{N}-\mathrm{N}-\mathrm{N})$ in $\mathrm{L}^{2}$. This observation characterizes the $\pi^{*}$ acceptor properties of the three L ligands. The cyclic voltammogram of complex I is shown in Fig. 2.

\section{Photophysical and photochemical properties}

Photoluminescence. The complexes are all luminescent at room temperature. Luminescence spectra were obtained in acetonitrile solution and the absorption peak lies near $600 \mathrm{~nm}$. 
Table 1 Electronic, ${ }^{a}$ emission ${ }^{a}$ and electroluminescence spectral data of the complexes

\begin{tabular}{|c|c|c|c|c|}
\hline \multirow{2}{*}{$\begin{array}{l}\text { Compounds } \\
{\left[\mathrm{Ru}(\mathrm{bpy})_{2}\left(\mathrm{~L}^{1}\right)\right]\left(\mathrm{PF}_{6}\right)_{2}}\end{array}$} & \multirow{2}{*}{$\begin{array}{l}\text { Absorbance maximum, } \mathrm{nm}, \\
\left(\varepsilon_{\max }, 10^{4}\right)\left(\mathrm{M}^{-1} \mathrm{~cm}^{-1}\right)\end{array}$} & \multicolumn{2}{|c|}{$\begin{array}{l}\text { PL max. (nm) \& quantum } \\
\text { yield (life time, ns) }\end{array}$} & \multirow{2}{*}{$\frac{\mathrm{EL} \max .(\mathrm{nm})}{582}$} \\
\hline & & 603 & $0.0071(129)$ & \\
\hline$\left[\mathrm{Ru}(\mathrm{bpy})_{2}\left(\mathrm{~L}^{2}\right)\right]\left(\mathrm{PF}_{6}\right)_{2}$ & $447(0.95), 417(1.12)$ & 598 & $0.0110(142)$ & 580 \\
\hline$\left[\mathrm{Ru}(\mathrm{bpy})_{2}\left(\mathrm{~L}^{3}\right)\right]\left(\mathrm{PF}_{6}\right)_{2}$ & $445(1.11), 420(1.10)$ & 602 & $0.0063(115)$ & 582 \\
\hline$\left[\mathrm{Ru}(\text { phen })_{2}\left(\mathrm{~L}^{1}\right)\right]\left(\mathrm{PF}_{6}\right)_{2}$ & $441(1.10), 414(1.17)$ & 585 & $0.0020(17)$ & 583 \\
\hline$\left[\mathrm{Ru}(\text { phen })_{2}\left(\mathrm{~L}^{2}\right)\right]\left(\mathrm{PF}_{6}\right)_{2}$ & $442(1.29), 414(1.17)$ & 601 & $0.0001(3)$ & 575 \\
\hline$\left[\mathrm{Ru}(\mathrm{bpy})_{3}\right]\left(\mathrm{PF}_{6}\right)_{2}$ (ref. 28 and 46) & $451(1.42), 345(0.650)$ & 620 & $0.0420(800)$ & 609 \\
\hline$\left[\mathrm{Ru}(\text { phen })_{3}\right]\left(\mathrm{PF}_{6}\right)_{2}($ ref. 28 and 46$)$ & $447(2.30), 420(2.10)$ & 589 & 0.0230 & 600 \\
\hline
\end{tabular}

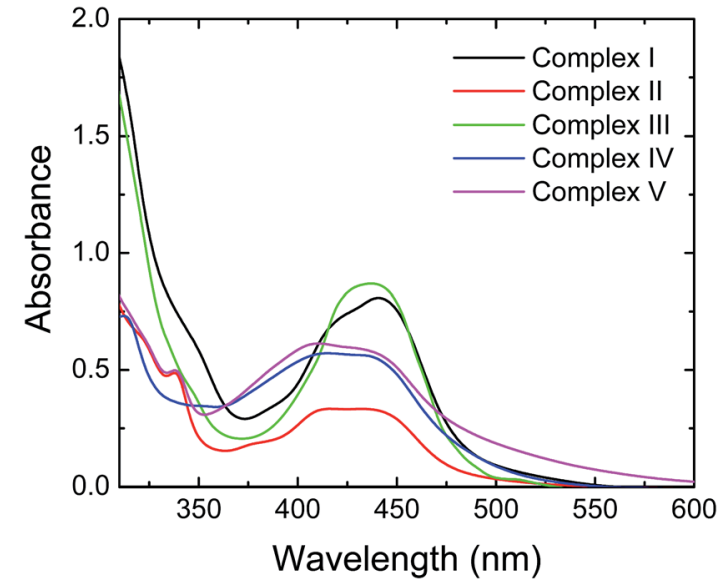

Fig. 1 Absorbance spectra of ruthenium complexes in acetonitrile solution.

Excitation spectral studies have demonstrated that the luminescence is associated with the above noted MLCT bands. The luminescence spectra are shown in Fig. 3. The $\left[\mathrm{Ru}(\mathrm{bpy})_{2}\left(\mathrm{~L}^{1}\right)\right]^{2+}$ and $\left[\mathrm{Ru}(\mathrm{bpy})_{2}\left(\mathrm{~L}^{3}\right)\right]^{2+}$ complexes show very similar luminescence properties, which are weaker compared to their corresponding $\mathrm{L}^{2}$ ligated analogues. The bipyridine co-ligated complexes are more luminescent than their phenanthroline co-ligated analogues. The maximum quantum yield is (ca. 0.011) in this family, slightly reduced compared to $\left[\mathrm{Ru}(\mathrm{bpy})_{3}\right]^{2+}\left(4 \mathrm{~d}^{6}\right)$ complex. This is opposite to the trend observed for $\operatorname{Re}(\mathrm{I})$ ligands, as $\left[\operatorname{Re}\left(\mathrm{L}^{1}\right)(\mathrm{CO})_{3} \mathrm{Cl}\right]$ has greater quantum yield compared to the $\left[\mathrm{Re}(\mathrm{bpy})(\mathrm{CO})_{3} \mathrm{Cl}\right]\left(5 \mathrm{~d}^{6}\right) \cdot{ }^{38,45}$ The photo-physical measurements

Table 2 Redox potentials of complexes in acetonitrile $v s$. SCE at $298 \mathrm{~K}$

\begin{tabular}{lll}
\hline Compounds & $\begin{array}{l}\mathrm{Ru}^{\mathrm{II}} / \mathrm{Ru}^{\mathrm{III}} E \\
(\mathrm{~V}),\left(\Delta E_{\mathrm{p}}, \mathrm{mV}\right)\end{array}$ & $\begin{array}{l}\text { Ligand/ligand } E \\
(\mathrm{~V}),\left(\Delta E_{\mathrm{p}}, \mathrm{mV}\right)\end{array}$ \\
\hline$\left[\mathrm{Ru}(\mathrm{bpy})_{2}\left(\mathrm{~L}^{1}\right)\right]\left(\mathrm{PF}_{6}\right)_{2}$ & $1.25(70)$ & $-1.41(100)$ \\
{$\left[\mathrm{Ru}(\mathrm{bpy})_{2}\left(\mathrm{~L}^{2}\right)\right]\left(\mathrm{PF}_{6}\right)_{2}$} & $1.30(80)$ & $-1.40(80)$ \\
{$\left[\mathrm{Ru}(\mathrm{bpy})_{2}\left(\mathrm{~L}^{3}\right)\right]\left(\mathrm{PF}_{6}\right)_{2}$} & $1.24(80)$ & $-1.43(100)$ \\
{$\left[\mathrm{Ru}(\mathrm{phen})_{2}\left(\mathrm{~L}^{1}\right)\right]\left(\mathrm{PF}_{6}\right)_{2}$} & $1.21(90)$ & $-1.42(90)$ \\
{$\left[\mathrm{Ru}(\mathrm{phen})_{2}\left(\mathrm{~L}^{2}\right)\right]\left(\mathrm{PF}_{6}\right)_{2}$} & $1.31(80)$ & $-1.40(70)$ \\
{$\left[\mathrm{Ru}(\mathrm{bpy})_{3}\right]\left(\mathrm{PF}_{6}\right)_{2}($ ref. 22, 47 and 48) } & $1.27(80)$ & $-1.31(70)$ \\
{$\left[\mathrm{Ru}(\mathrm{phen})_{3}\right]\left(\mathrm{PF}_{6}\right)_{2}$ (ref. 28, 47 and 48) } & 1.19 & -1.44
\end{tabular}

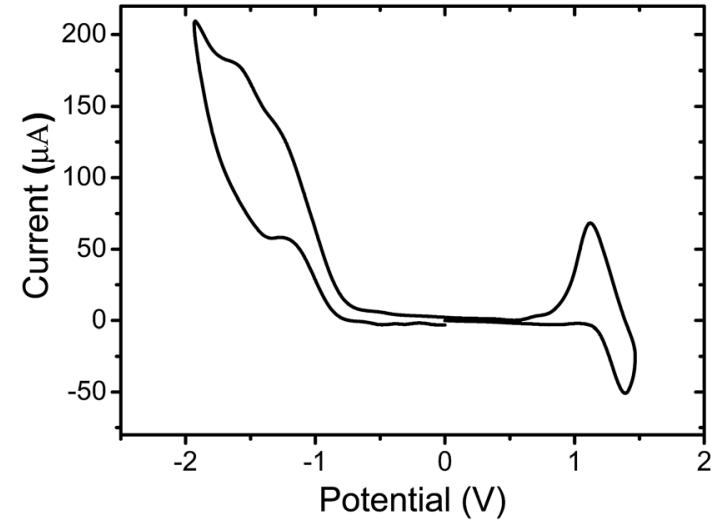

Fig. 2 Cyclic voltammogram of $\left[\mathrm{Ru}(\mathrm{bpy})_{2}\left(\mathrm{~L}^{1}\right)\right]\left(\mathrm{PF}_{6}\right)_{2}$ complex in acetonitrile solution at platinum working electrode (scan rate $100 \mathrm{mV} \mathrm{s}^{-1}$ ).

are listed in Table 1. It is interesting to note that the pyridyltriazine complex of ruthenium(II) with two bpy co-ligands is not photoluminescent, while the pyridyltriazine complex of rhenium(I) with three carbonyls and a halide co-ligand is photoluminescent, despite the structural similarity of the triazine and triazolo rings. ${ }^{38}$

Electroluminescence. To study the solid-state electroluminescence properties of the ruthenium complexes, we first measured the current-voltage and light-voltage characteristics of the thin film devices comprised only of the materials sandwiched between ITO and aluminum electrodes. Fig. 4 shows

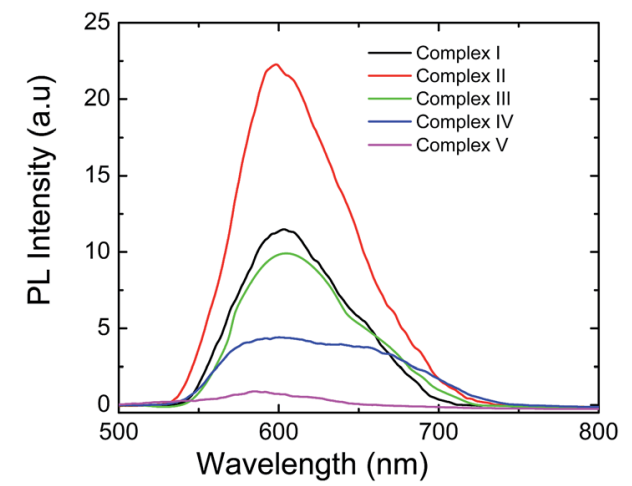

Fig. 3 Photoluminescence spectra of the complexes in acetonitrile solution. 


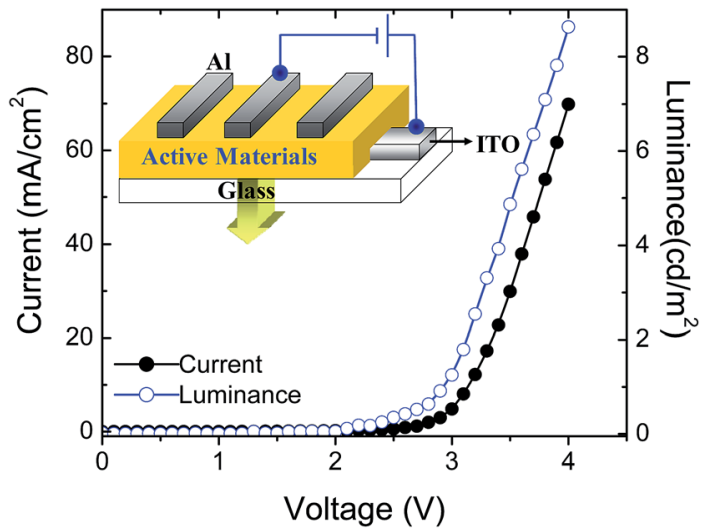

Fig. 4 Current-voltage (solid circle) and luminance-voltage (open circle) graphs of the ITO/ruthenium complex I/Al device. The schematic device structure is shown in the inset figure.

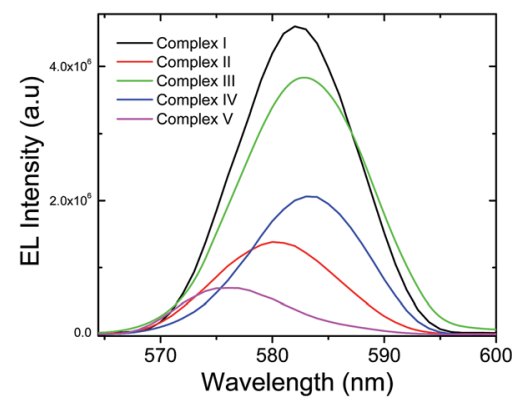

Fig. 5 Electroluminescence spectra of ITO/ruthenium complexes $(\mathrm{I}-\mathrm{V}) / \mathrm{Al}$ devices under $6.00 \mathrm{~V}$ bias.

light-voltage and current-voltage curves for a typical ITO/ ruthenium complex I/Al device. In forward bias (ITO as the anode), devices turn on uniformly at relatively low voltages. The $I-V$ characteristic of the devices shows asymmetric nature with high rectification ratio. The electroluminescence of the devices start at voltage $2.6 \mathrm{~V}$ and increases with the increase of the forward bias. It is also observed that the light emission in the reverse bias (ITO as cathode) is negligible in theses devices. All the complexes are electroluminescent in nature. $\mathrm{L}^{1}$ ligated complexes (I and IV) with bpy and phen coligands exhibit better electroluminescence properties compared to their $\mathrm{L}^{2}$ ligated analogues (II and V). The complexes I and III show comparable electroluminescence and photoluminescence properties due to the similarity of $\mathrm{L}^{1}$ and $\mathrm{L}^{3}$ ligands with respect to the position of nitrogen in the heterocyclic rings. The $\mathrm{L}^{1}$ and $\mathrm{L}^{3}$ ligated complexes show weaker photoluminescence and stronger electroluminescence properties compare to their $\mathrm{L}^{2}$ ligated analogue. Maximum brightness, about $8.6 \mathrm{~cd} \mathrm{~m}^{-2}$ at $4.00 \mathrm{~V}$, was observed for complex I. Quantum efficiency of the devices is in the range of $0.02-0.04 \%$ photons/electron at $3.00 \mathrm{~V}$, which is lower than the standard $\mathrm{Ru}(\mathrm{bpy})^{3+}$ complex at $3.00 \mathrm{~V}^{28}$

The electroluminescence spectra of the ruthenium complexes I-V are taken by applying $6.00 \mathrm{~V}$ forward bias, which are shown in the Fig. 5. Visible yellow light emission spectra were observed from these devices.
The response time of light-emitting electrochemical cells has always been a hindrance for their practical application. In general, the response time can be decreased by increasing the ionic conductivity of the ion-containing phase. This is especially effective in $\left[\mathrm{Ru}(\mathrm{bpy})_{3}\right]^{2+}$ type devices since the light emission and ion conduction occurs within the same phase. The ionic conductivity of $\left[\mathrm{Ru}(\mathrm{bpy})_{3}\right]^{2+}$ devices can be increased by changing the chemical structure of the $\left[\mathrm{Ru}(\mathrm{bpy})_{3}\right]^{2+}$ type complex or by decreasing the size of the mobile counter ions. ${ }^{26}$

\section{Conclusion}

Here we report the spectroscopic, electrochemical, photophysical and photochemical properties of a family of isoelectronic nitrogen rich cyclic aza-/azo-aromatic complexes of ruthenium. To the best of our knowledge, studies of electroluminescent devices incorporating this class of complexes have not been reported. While electroluminescent devices containing $\mathrm{Ru}(\mathrm{II})$ complexes of aryltetrazole ligands have been reported, the mode of binding of aryltetrazole ligands is different.

Although the highest photoluminescence efficiency of this family is slightly reduced compared to the parent $\left[\mathrm{Ru}(\mathrm{bpy})_{3}\right]^{2+}$ complex, the highest electroluminescence of this family is comparable to $\left[\mathrm{Ru}(\mathrm{bpy})_{3}\right]^{2+}$. The photoluminescence and electroluminescence properties of $\mathrm{L}^{1}$ and $\mathrm{L}^{3}$ ligated complexes are almost similar, whereas their $\mathrm{L}^{2}$ ligated analogues exhibit different activities. So, the photo-physical and photo-chemical properties of this family depend mainly on nitrogen positions rather than the position of fused pyridine ring. From the present work, it is clear that in this particular family of ligands, increasing the number of nitrogen atoms in the heterocyclic ring reduces the photo-physical and photo-chemical efficiencies of the ruthenium complex based system significantly, unlike in the $\left[\operatorname{Re}\left(\mathrm{L}^{1}\right)(\mathrm{CO})_{3} \mathrm{Cl}\right]$ system, where increasing nitrogen atoms in the ligand framework results in greater quantum yield than the parent $\left[\mathrm{Re}(\mathrm{bpy})(\mathrm{CO})_{3} \mathrm{Cl}\right]\left(5 \mathrm{~d}^{6}\right)$. Also, transition metal complexes of iridium and platinum function efficiently as light-emitting self-assembled materials, despite containing a number of nitrogens in the heterocyclic ring. So the logical next step would be studying photo-redox properties of cyclometalated iridium and platinum metal complexes with a library of benzyltriazolopyridine (isobars of pyridyltriazolopyridine) ligands, to explore the effects of different positions and numbers of nitrogen in the heterocyclic ring. That study is in progress.

\section{Acknowledgements}

The authors thankfully acknowledge the laboratory support provided by Prof. A. Chakravorty, and Prof. A. J. Pal of Indian Association for the Cultivation of Science, Kolkata, India. The authors also thank Dr Priyabrata Banerjee for his advice and suggestions regarding chemical synthesis. The authors acknowledge Dr Arundhati Nag for helping us in compiling the manuscript. This work is partially supported by the Department of Science and Technology (Project No. -SB/FTP/PS-148/2013, and SR/S2/RJN-55/2012) and Council of Scientific and Industrial Research, India. 


\section{References}

1 C. Creutz and N. Sutin, Proc. Natl. Acad. Sci. U. S. A., 1975, 72, 2858.

2 F. P. Rotzinger, S. Munavalli, P. Comte, J. K. Hurst, M. Grätzel, F. J. Pern and A. J. Frank, J. Am. Chem. Soc., 1987, 109, 6619.

3 P. Comte, M. K. Nazeeruddin, F. P. Rotzinger, A. J. Frank and M. Grätzel, J. Mol. Catal., 1989, 52, 63.

4 J. K. Hurst, J. L. Cape, A. Clark, S. Das and C. Qin, Inorg. Chem., 2008, 47, 1753.

5 F. Lui, J. J. Concepcion, T. Cardolaccia, J. W. Jurss and T. J. Meyer, Inorg. Chem., 2008, 47, 1727.

6 N. P. Cook, V. Torres, D. Jain and A. A. Martí, J. Am. Chem. Soc., 2011, 133, 11121.

7 K. Huang, C. Jiang and A. A. Martí, J. Phys. Chem. A, 2014, 118, 10353.

8 A. Fujishima and K. Honda, Nature, 1972, 238, 37.

9 B. O. Regan and M. Grätzel, Nature, 1991, 335, 737.

10 K. Kalyanasundaram and M. Grätzel, Coord. Chem. Rev., 1998, 77, 347.

11 M. Grätzel, Inorg. Chem., 2005, 44, 6841.

12 G. J. Meyer, Inorg. Chem., 2005, 44, 6852.

13 M. K. Nazeeruddin, Q. Wang, L. Cevey, V. Aranyos, P. Liska, E. Figgemeier, C. Klein, N. Hirata, S. Koops, S. A. Haque, J. R. Durrant, A. Hagfeldt, A. B. P. Lever and M. Grätzel, Inorg. Chem., 2006, 45, 787.

14 P. Z. Hoertz, A. Staniszewski, A. Marton, G. T. Higgins, C. D. Incarvito, A. L. Rheingold and G. J. Meyer, J. Am. Chem. Soc., 2006, 128, 8234.

15 R. H. Bowman and K. Mislow, J. Am. Chem. Soc., 1972, 94, 2862.

16 J.-K. Lee, D. Yoo, E. S. Handy and M. F. Rubner, Appl. Phys. Lett., 1996, 69, 1686.

17 K. M. Maness, R. H. Terrill, T. J. Meyer, R. W. Murray and R. M. Wightman, J. Am. Chem. Soc., 1996, 118, 10609.

18 J. K. Lee, D. Yoo and M. F. Rubner, Chem. Mater., 1997, 9, 1710.

19 K. M. Maness, H. Masui, R. M. Wightman and R. W. Murray, J. Am. Chem. Soc., 1997, 119, 3987.

20 C. M. Elliott, F. Pichot, C. J. Bloom and L. S. Rider, J. Am. Chem. Soc., 1998, 120, 6781.

21 C. H. Lyons, E. D. Abbas, J.-K. Lee and M. F. Rubner, J. Am. Chem. Soc., 1998, 120, 12100.

22 E. S. Handy, A. J. Pal and M. F. Rubner, J. Am. Chem. Soc., 1999, 121, 3525.
23 M. M. Collinson, J. Taussig and S. A. Martin, Chem. Mater., 1999, 11, 2594.

24 F. G. Gao and A. J. Bard, J. Am. Chem. Soc., 2000, 122, 7426.

25 H. Rudmann and M. F. Rubner, J. Appl. Phys., 2001, 90, 4338.

26 H. Rudmann, S. Shimada and M. F. Rubner, J. Am. Chem. Soc., 2002, 124, 4918.

27 M. Buda, G. Kalyuzhny and A. J. Bard, J. Am. Chem. Soc., 2002, 124, 6090.

28 S. Bernhard, J. A. Barron, P. L. Houston, H. D. Abruna, J. L. Ruglovksy, X. Gao and G. G. Malliaras, J. Am. Chem. Soc., 2002, 124, 13624.

29 S. Welter, K. Brunner, J. W. Hofstraat and L. D. Cola, Nature, 2003, 421, 54.

30 G. Kalyuzhny, M. Buda, J. McNeill, P. Barbara and A. J. Bard, J. Am. Chem. Soc., 2003, 125, 6272.

31 H. Xia, C. Zhang, X. Lui, S. Qiu, P. Lu, F. Shen, J. Zhang and Y. Ma, J. Phys. Chem. B, 2004, 108, 3185.

32 M. M. Richter, Chem. Rev., 2004, 104, 3003.

33 W. Zhao, C. Y. Lui, Q. Wang, J. M. White and A. J. Bard, Chem. Mater., 2005, 17, 6403.

34 S. Scholz, D. Kondakov, B. Lüssem and K. Leo, Chem. Rev., 2015, 115, 8449.

35 S. Zanarini, A. J. Bard, M. Marcaccio, A. Palazzi, F. Paolucci and S. Stagni, J. Phys. Chem. B, 2006, 110, 22551.

36 V. W. W. Yam, V. K. M. Au and S. Y. L. Leung, Chem. Rev., 2015, 115(15), 7589.

37 J. B. Godwin and T. J. Meyer, Inorg. Chem., 1971, 10, 471.

38 S. Das and B. K. Panda, Polyhedron, 2006, 25, 2289.

39 B. Pradhan and S. Das, Chem. Mater., 2008, 20, 1209.

40 L. P. Battaglia, M. Carcelli, F. Ferraro, L. Marvilla, C. Pelizzi and G. Pelizzi, J. Chem. Soc., Dalton Trans., 1994, 2651.

41 Kanebo, Ltd., Japan, Jpn. Kokai Tokkyo Koho, JP 56100783 A2 19810812 Showa, 1981, 5.

42 C. M. Fitchett, F. R. Keene, C. Richardson and P. J. Steel, Inorg. Chem. Commun., 2008, 11, 595.

43 S. Das, Inorg. Chim. Acta, 2008, 361, 2815.

44 S. Das and A. Chakravoty, Eur. J. Inorg. Chem., 2006, 2285.

45 D. P. Rillema, D. G. Taghdiri, D. S. Jone, L. A. Worl, T. J. Meyer, H. A. Levy and C. D. Keller, Inorg. Chem., 1987, 26, 578 .

46 B. Durham, J. V. Caspar, J. K. Nagle and T. J. Meyer, J. Am. Chem. Soc., 1982, 104, 4803.

47 L. F. Cooley, C. E. L. Headford, C. M. Elliott and D. F. Kelley, J. Am. Chem. Soc., 1988, 110, 6673.

48 J. V. Caspar and T. J. Meyer, Inorg. Chem., 1983, 22, 2444. 